\title{
Determination of Hydroxyl Radical in Seto Inland Sea and its Potential to Degrade Irgarol
}

\author{
Olasehinde, E.F. ${ }^{1,2}$, Ogunsuyi, H.O. ${ }^{2}$, Sakugawa, $\mathrm{H}^{1}$. \\ ${ }^{I}$ (Graduate School of Biosphere Science, Hiroshima University, Japan) \\ ${ }^{2}$ (Department of Chemistry, Federal University of Technology, Akure, Nigeria)
}

\begin{abstract}
Photo-production rates and overall scavenging rate constants of the highly reactive hydroxyl radicals $(\cdot \mathrm{OH})$ were measured by irradiation of surface seawater samples collected from the Seto Inland Sea, Japan. Photo-production rates of $\cdot \mathrm{OH}$ ranged from $7.2 \times 10^{-12} \mathrm{M} \mathrm{s}^{-1}$ to $424 \times 10^{12} \mathrm{M} \mathrm{s}^{-1}$ and scavenging rate constants were $1.3-4.1 \times 10^{6} s^{-1}$. The steady state concentrations of $\bullet \mathrm{OH}$ in seawater, which were calculated from the photo-production rates and scavenging rate constants were in the range $2.6-189 \times 10^{-18} \mathrm{M}$. Estimation from the scavenging rate constant showed that the lifetime of $\bullet \mathrm{OH}$ in seawater ranged from 0.29 $\times 10^{-6}$ s to $0.55 \times 10^{-6}$ s. Nitrates and hydrogen peroxide contributions to $\mathrm{OH}$ radical formation rates were negligible in the samples studied. However, direct photolysis of $\mathrm{NO}_{2}{ }^{-}$accounted for up to $73 \%$ of the observed -OH formation rates. The rate constant for the reaction $\cdot \mathrm{OH}$ with irgarol was found to be $(9.7 \pm 0.52) \times 10^{9} \mathrm{M}$ ${ }^{1} s^{-1 .}$ Based on the steady state concentration of $\bullet \mathrm{OH}$, the calculated half-lives for Irgarol due to the reaction with hydroxyl radicals in the Seto Inland Sea were in the range 4.3-318 days.
\end{abstract}

Keywords - Hydroxyl radical, irgarol, photochemistry, rate constant, seawater

\section{INTRODUCTION}

The absorption of solar irradiations in the UV region by the constituents of natural water leads to the production of transient species [1, 2]. These include $\mathrm{H}_{2} \mathrm{O}_{2}$ [3,4], hydrated electrons [5], superoxide ion [6] organo peroxyl radicals [7], hydroxyl radicals $[1,2,8]$ and nitric oxide radicals [9-11] These species are reactive and play important roles in chemical and biological processes in aquatic environments, such as photochemical degradation of natural organic matter and organic pollutants, redox reactions and biological reactions [12-14]. Among the reactive species that can be photochemically generated in natural waters, hydroxyl radicals play an important role because of the elevated reaction rate constants towards a very wide variety of organic and inorganic compounds [15]. It reacts fairly non selectively with organic compounds by hydrogen abstraction or hydroxyl addition, with a typical rate constant of $\sim 10^{-9} \mathrm{M}^{-1} \mathrm{~s}^{-1}$ [12]. Due to its high reactivity with organic compounds, $\cdot \mathrm{OH}$ has been implicated in the degradation of recalcitrant organic compounds that are resistant to chemical, biological and direct photochemical decomposition $[12,14,16]$.

Hydroxyl radicals may be generated in surface waters by three major processes: photolysis of nitrate ion $\left(\mathrm{NO}_{3}{ }^{-}\right)$[17], nitrite ion $\left(\mathrm{NO}_{2}{ }^{-}\right.$and $\left.\mathrm{HNO}_{2}\right)$ [16,18], hydrogen peroxide $\left(\mathrm{H}_{2} \mathrm{O}_{2}\right)$ [19], direct photolysis of dissolved organic matters (DOM) [1] and the photofenton reaction [5, 20, 21] in water containing sufficient iron concentrations. However, the reactions of ${ }^{\circ} \mathrm{OH}$ with $\mathrm{Cl}^{-}, \mathrm{Br}^{-}, \mathrm{HCO}_{3}{ }^{-}$and $\mathrm{DOM}$ have been identified as the possible pathways for $\cdot \mathrm{OH}$ loss in natural waters [1]. Due to the high reactivity and short lifetime, the steady state concentrations of $\bullet \mathrm{OH}$ in natural waters are generally very low and thus it is difficult to monitor directly [8]. Based on this, the photochemical formation rates of $\bullet \mathrm{OH}$ are determined by indirect methods using probe compounds to scavenge the $\cdot \mathrm{OH}$ produced. These include: isopropylbenzene [7], n-butylchloride, methyl mercury, nitrobenzene, anisole [16] methanol and benzoic acid [1] and benzene [22].

In this study, benzene was selected because of its advantages namely: the second order rate constant for the reaction of $\bullet \mathrm{OH}$ with benzene $\left(7.8 \times 10^{9} \mathrm{M}^{-1} \mathrm{~s}^{-1}\right)$ is higher than the rate constant for the reaction of $\bullet \mathrm{OH}$ with methanol $\left(9.7 \times 10^{8} \mathrm{M}^{-1} \mathrm{~s}^{-1}\right)$ and benzoic acid $\left(4.3 \times 10^{9} \times \mathrm{M}^{-1} \mathrm{~s}^{-1}\right)$ [15]. Benzene does not absorb lamp radiation (absence of direct photolysis to phenol was checked) and does not alter either the $\mathrm{pH}$ or the buffer capacity of the solutions [23].

Irgarol 1051 , a s-triazine herbicide used in copper based antifouling paints, has been widely detected in fresh waters and seawaters around the world [24 -26]. It has been shown that Irgarol is acutely toxic to corals, mangroves and sea grasses, inhibiting photosynthesis at low concentrations (>50 ng $\left.1^{-1}\right)$. Of a particular concern, this compound has been detected in the Seto Inlad sea with a high concentration, up to $0.26 \mu \mathrm{g} / \mathrm{L}$ [24] Meanwhile, irgarol has been reported to be stable to biodegradation, heat and hydrolysis [27].

To the best of our knowledge, the determination of the photoformation rate and the scavenging rate constants of hydroxyl radicals for the entire Seto Inland Sea has not been reported in the world literature. Therefore, this study attempted to: (a) determine the photo-formation rates, scavenging rate constants, steadystate concentrations and the lifetimes of $\bullet \mathrm{OH}$ in the Seto Inland Sea, (b) identify the major sources and sinks (c) 
estimate the lifetime of an herbicidal compound, irgarol, due to the reaction with $\bullet \mathrm{OH}$ in the in the Seto Inland Sea.

\section{EXPERIMENTAL}

\subsection{Reagents and Chemicals}

All reagents were reagent grade and used as received unless otherwise stated. All solutions were prepared with ultra-pure water obtained from a Milli-Q Plus system (Millipore; $\geq 18.2 \mathrm{M} \Omega \mathrm{cm}$ ). Acetonitrile and benzene were purchased from Nacalai Tesque (HPLC grade > 99.5\%). Commercial phenol standard stock solution (100 mg L $\mathrm{m}^{-1}$ of phenol) and potassium hydrogen phthalate were purchased from Sigma- Aldrich Japan. Irgarol was obtained from Sigma-Aldrich Laborchemikalien (Seelze, Germany). Sodium nitrite, sodium nitrate, sodium chloride, sodium sulphate, Iron (II) sulphate, sulphanilamide, were purchased from Katayama Chemical Industries (Guaranteed grade). $\mathrm{H}_{2} \mathrm{O}_{2}$ stock solution (ca.30\%) was obtained from Wako Pure Chemical Industries and the concentration of the diluted stock solution was determined based on the molar extinction coefficient at $240 \mathrm{~nm}\left\{\varepsilon=38.1 \mathrm{M}^{-1} \mathrm{~cm}^{-1}\right.$ [28] 2-Nitrobenzaldehyde and N-1-naphthylethelenediamine dichloride were purchased from Tokyo Kasei Kogyo.

\subsection{Water Samples}

Surface seawater (salinity 28.8.-33.7\%, pH 8.0 - 8.2) samples from various locations were collected from the Seto Inland Sea using Niskin sampling bottles and a Sea-Bird CTD carousel multi sampling system (SBE-9plus). Samplings were conducted during the cruise of Hiroshima University's R/V Toyoshio Maru on September 3-4, 2007; October $20-24,2008$, and October 5-9, 2009. The sampling stations are shown in Fig. 1. Samples were immediately transferred to clean $1 \mathrm{~L}$ amber glass bottles. Water samples were filtered through a pre-cleaned glass fiber filter (Advantech, $0.45 \mu \mathrm{m}$ nominal rating) and stored in the dark at $4{ }^{\circ} \mathrm{C}$ until analysis. Analyses were completed within 2 weeks of sample collection.

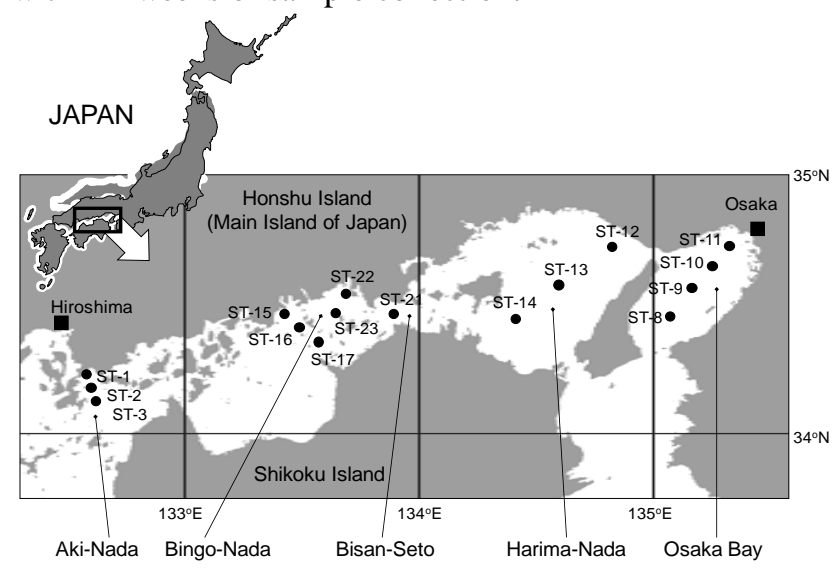

Fig. 1: Map showing the sampling locations in the Seto Inland Sea

\subsection{Irradiation Experiments}

In the irradiation experiments, a solar simulator (Oriel model 81160-1000, Oriel Corp.) equipped with a $300 \mathrm{~W}$ Xe lamp (ozone free, model 6258, Oriel Corp.) was used. To simulate actual solar irradiance, wavelengths less than $300 \mathrm{~nm}$ were filtered out by optical filters (Oriel AM 0 and AM1.0, Oriel Instruments). Derbalah et al., 2004. The photochemical reactions were performed in a custom-made quartz glass cell (Workshop for Advanced Techniques, Hiroshima University). The quartz glass reaction cell was $5 \mathrm{~cm}$ in diameter, $1.5 \mathrm{~cm}$ in length and had a $20 \mathrm{~mL}$ capacity. The solution inside the cell was gently stirred with a Teflon stirring bar and maintained at ca. $20{ }^{\circ} \mathrm{C}$ using a Neslab RTE 111 recirculating water bath. The daily actinic flux of the solar simulator was determined by measuring the degradation rate of an $8 \mu \mathrm{M}$ standard solution of 2-NB using the same quartz cell that was used for the photochemical experiments. The apparent first-order photolysis rate constant for the degradation of 2-nitrobenzaldehyde $\left(J_{2 \mathrm{NB}}\right)$ was determined by HPLC with a UV detector set at an absorbance wavelength of $260 \mathrm{~nm}$. The separations were carried out on the same column as that used for the $\cdot \mathrm{OH}$ determinations, with an acetonitrile - water mixture $(40 / 60, \mathrm{v} / \mathrm{v})$ as eluent at a flow rate of $1 \mathrm{~mL} \mathrm{~min}^{-1}$. The $J_{2 \mathrm{NB}}$ values for the solar simulator ranged from 0.0094 to $0.0057 \mathrm{~s}^{-1}$. However, all data related to photochemical reactions were normalized to a 2-NB degradation rate of $0.0093 \mathrm{~s}^{-1}$ which was determined at noon under clear sky conditions in Higashi - Hiroshima city $\left(34^{\circ} 25^{\prime} \mathrm{N}\right)$ on May 1, 1998 [22]

\subsection{Ancillary measurements}

Nitrate and Nitrite were determined spectrophotometrically by a HITACHI K-1000 flow-injection analyzer equipped with and without a home-made copperized cadmium column [29]. Hydrogen peroxide was 
determined by the method described by Olasehinde et al. [30]. The concentration of dissolved organic carbon (DOC) was determined by using a Shimadzu TOC5000A TOC Analyzer.

\subsection{General procedures of $\mathrm{OH}$ radical determination in seawater}

The method for the determination of $\mathrm{OH}$ radicals in seawater is essentially that described by Arakaki et al [22]. To determine the $\bullet \mathrm{OH}$ photoformation rates, seawater samples with $1.2 \mathrm{mM}$ benzene were irradiated in the same quartz glass cell that was used for the determination of 2-NB degradation rate. The irradiated samples with the probe were withdrawn at regular intervals for HPLC analysis. The phenol formed due to the reaction of the photo-formed $\cdot \mathrm{OH}$ with benzene was analyzed by reversed-phase HPLC system equipped with RP-18 GP column $(150 \times 4.6 \mathrm{~mm}$ I.D., $5 \mu \mathrm{m})$ column. The fluorescence detector was operated at excitation and emission wavelengths of 270 and $298 \mathrm{~nm}$, respectively. The mobile phase was $\mathrm{CH}_{3} \mathrm{CN}: \mathrm{H}_{2} \mathrm{O}=40: 60(\mathrm{v} / \mathrm{v})$, with a flow rate of $1 \mathrm{~mL} \mathrm{~min}{ }^{-1}$. The concentration of phenol was determined by using a calibration standard prepared and run on the same day of the illumination experiment. The photoformation rate of phenol $\left(R_{\mathrm{p}}\right)$ was determined from the slope of the plots of total concentration of phenol versus cumulative irradiation time using a linear regression fit. Thus, the $\cdot \mathrm{OH}$ photoformation rate $\left(R_{\mathrm{OH}}\right)$ was calculated by:

$R_{\mathrm{OH}}=R_{\mathrm{p}} / F_{\mathrm{b}} \times Y_{\mathrm{p}}$

where $R_{\mathrm{p}}$ is the photoformation rate of phenol in water samples $\left(\mathrm{M} \mathrm{s}^{-1}\right), Y_{\mathrm{p}}$ the yield of phenol formed per benzene oxidized $\bullet \mathrm{OH}$ (Mean \pm standard deviation $=0.75 \pm 0.07$ [23] and $F_{\mathrm{b}}$ the fraction of $\bullet \mathrm{OH}$ that reacts with benzene. $F_{b}$ in Seto Inland Sea seawater samples was reported to be 0.68 [8]. For the purpose of calculating $R_{\mathrm{OH}}$ in (1), the values for $Y_{\mathrm{p}}$ and $F_{\mathrm{b}}$ were used accordingly.

For the determination of the scavenging rate constants $\left(\sum\left(k_{\mathrm{s}}, \mathrm{OH}[\mathrm{S}]\right)\right.$, aliquots of benzene stock solution were added to different aliquots of the seawater sample to give initial benzene concentrations from $0.2-2.0 \mathrm{mM}$. The solutions were irradiated for a total period of $60 \mathrm{~min}$ and analyzed for phenol at regular intervals. A Plot of $1 / R_{\text {phenol }}$ against $1 /$ [benzene] yields a straight line (Fig.2). From the results of the least square regression line for the relationship between $1 / R_{\text {phenol }}$ and $1 /$ benzene, $\sum\left(k_{\mathrm{s}}, \mathrm{OH}[\mathrm{S}]\right)$ in the water samples was calculated by using the y-intercept, slope and the rate constant of benzene for the reaction with $\bullet \mathrm{OH}\left(k_{\mathrm{b}}, \mathrm{OH}: 7.8 \times 10^{9} \mathrm{M}^{-1} \mathrm{~s}^{-1},[15]\right)$ as follows:

$\sum\left(k_{\mathrm{s}}, \mathrm{OH}[\mathrm{S}]\right)=$ slope $\times k_{\mathrm{b}}$, он $/$ y-intercept

The $\cdot \mathrm{OH}$ lifetime $\left(\tau_{\mathrm{OH}}\right)$ can then be defined as:

$\tau_{\mathrm{OH}}=1 / \sum\left(k_{\mathrm{s}}, \mathrm{OH}[\mathrm{S}]\right)$

and steady-state concentrations of $\mathrm{OH}$ radicals were estimated by using (4).

$[\cdot \mathrm{OH}]_{\mathrm{ss}}=\mathrm{R}_{\mathrm{OH}} / \sum\left(k_{\mathrm{s}}, \mathrm{OH}[\mathrm{S}\right.$

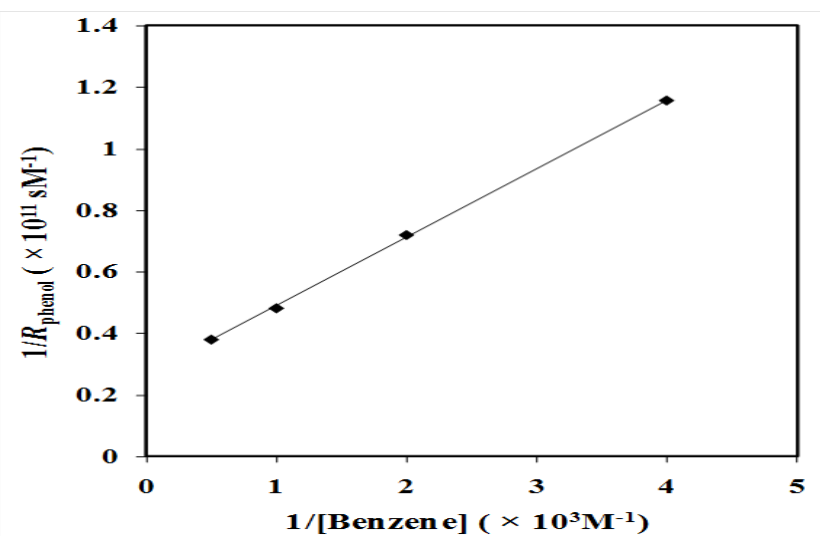

Figure 2: Relationship between $1 / R_{\text {phenol }}$ and $1 /$ [benzene] in seawater. The values for the y-intercept and slope are $2.27 \times 10^{10} \mathrm{sM}^{-1}$ and $2.23 \times 10^{7} \mathrm{~s}$, respectively. Correlation coefficient $\left(r^{2}\right)=0.997$

\section{RESULTS AND DISCUSSION}

\subsection{Rate constants for $\bullet \mathrm{OH}$ formation from the photolysis of nitrate, nitrite and hydrogen peroxide}

Table 1 shows the results of $\bullet \mathrm{OH}$ photoformation rate constants $\left(J_{\mathrm{i}, \mathrm{OH}}\right)$ from the photolysis of $\mathrm{NO}_{2}{ }^{-}$, $\mathrm{NO}_{3}{ }^{-}$and $\mathrm{H}_{2} \mathrm{O}_{2}$ in aqueous solutions. Photoformation rate constants of hydroxyl radicals were calculated using the following relationship:

$R_{\mathrm{i}, \mathrm{OH}}=J_{\mathrm{i}, \mathrm{OH}}[\mathrm{i}]$

where $R_{\mathrm{i}, \mathrm{OH}}\left(\mathrm{M} \mathrm{s}^{-1}\right)$ is the $\mathrm{OH}$ photoformation rates from " $\mathrm{i}$ ", and [i] is the concentration (M) of $\mathrm{NO}_{2}{ }^{-}, \mathrm{NO}_{3}{ }^{-}$and $\mathrm{H}_{2} \mathrm{O}_{2}$. To estimate the $J_{\mathrm{i}, \mathrm{OH}}, \cdot{ }^{\circ} \mathrm{OH}$ photoformation rates were determined by the irradiation of sodium nitrate $(50-250 \mu \mathrm{M})$, sodium nitrite $(1-5 \mu \mathrm{M})$ and hydrogen peroxide $(20-100 \mu \mathrm{M})$ solutions. The concentration of photochemically formed phenol increased linearly with an increase in the concentrations of $\mathrm{NO}_{2}{ }^{-}, \mathrm{NO}_{3}{ }^{-}$and $\mathrm{H}_{2} \mathrm{O}_{2}$. Thus, $J_{\mathrm{i}, \mathrm{OH}}$ was estimated from the plots of $R_{\mathrm{i}, \mathrm{OH}}$ versus concentrations of " $\mathrm{i}$ " by linear 
Determination of Hydroxyl Radical in Seto Inland Sea and its Potential to Degrade Irgarol regression analysis. The results obtained in this study are in good agreement with those previously reported [1, 8].

Table 1. The rate constant $\left(\mathrm{s}^{-1}\right)$ for $\bullet \mathrm{OH}$ photoformation from the photolysis of nitrate, nitrite and hydrogen peroxide in water

\begin{tabular}{llllll}
\hline $\begin{array}{l}\text { Light } \\
\text { source }\end{array}$ & Sample & $\mathrm{NO}_{3}{ }^{-}$ & $\mathrm{NO}_{2}{ }^{-}$ & $\mathrm{H}_{2} \mathrm{O}_{2}$ & Reference \\
\hline Xe lamp & Seawater & $2.28 \times 10^{-7}$ & $2.45 \times 10^{-5}$ & $3.2 \times 10^{-6}$ & This study \\
Xe lamp & Milli-Q & $2.40 \times 10^{-7}$ & $2.67 \times 10^{-5}$ & $4.1 \times 10^{-6}$ & This study \\
Xe lamp & Seawater & $1.63 \times 10^{-7}$ & $2.24 \times 10^{-5}$ & $2.10 \times 10^{-6}$ & ${\text { Takeda } \text { et al. }(2004)^{\mathrm{a}}}^{\mathrm{a}}$ \\
Sunlight & Seawater & $3.00 \times 10^{-7}$ & $2.30 \times 10^{-5}$ & $4.10 \times 10^{-6}$ & ${\text { Mopper } \text { et al. }(1990)^{\mathrm{b}}}^{\mathrm{b}}$ \\
Xe lamp & MilliQ & $1.79 \times 10^{-7}$ & $2.07 \times 10^{-5}$ & $3.36 \times 10^{-6}$ & ${\text { Takeda } \text { et al. }(2004)^{\mathrm{a}}}^{\mathrm{a}}$ \\
Xe lamp & MilliQ & $2.53 \times 10^{-7}$ & $2.76 \times 10^{-5}$ & $2.76 \times 10^{-6}$ & ${\text { Nakatani } \text { et al. }(2007)^{\mathrm{c}}}^{\mathrm{c}}$ \\
Sunlight & MilliQ & $2.43 \times 10^{-7}$ & $2.81 \times 10^{-5}$ & $3.52 \times 10^{-6}$ & ${\text { Arakaki } \text { et al. }(1998)^{\mathrm{d}}}^{\mathrm{d}}$ \\
\hline
\end{tabular}

c, d Rate constants normalized to $\mathrm{J}_{2-\mathrm{NB}}=0.0093 \mathrm{~s}^{-1}$.

a Rate constants normalized to $\mathrm{J}_{2-\mathrm{NB}}=0.00854 \mathrm{~s}^{-1}$

b Rate constant normalized to natural sunlight at midday, midsummer, latitude $50^{\circ} \mathrm{N}$

\subsection{Photoformation rates of $\bullet \mathrm{OH}$ in Seto Inland Sea}

The hydroxyl radical photoformation rates in the Seto Inland Sea are reported in Table 2. As shown in the Table, $\cdot \mathrm{OH}$ photoformation rates ranging from $7.2 \times 10^{-12} \mathrm{M} \mathrm{s}^{-1}$ in Bingo nada to $424 \times 10^{-12} \mathrm{M} \mathrm{s}^{-1}$ in Osaka bay were measured in the Seto Inland Sea. Hydroxyl radical formation rates ranging from $2.8-8.2 \times 10^{-12} \mathrm{M} \mathrm{s}^{-1}$ [1] and $5.7-49.5 \times 10^{-12}$ [31] have been reported for open-ocean surface waters and coastal waters, respectively. This indicates that $\bullet \mathrm{OH}$ formation rates in Osaka bay are one order of magnitude higher than those reported for other coastal waters. The reason for this discrepancy is presently unclear. However, Osaka Bay has been described as a semi-enclosed bay surrounded by many factories and residential areas. Moreover, the major rivers such as Yodo River, Yamato River, Kanzaki River and so on, empty into Osaka Bay through the big cities, Kyoto, Osaka, [32]. Annual flow of fresh water from two large rivers, the Yodo River and the Yamato River, is about $14 \mathrm{~km}^{3} \mathrm{yr}^{-1}$ and this value corresponds to one-third of the total seawater volume of Osaka bay [33]. Meanwhile, previous report had established that very elevated $\mathrm{OH}$ formation rates $\left(\sim 10^{-10} \mathrm{M} \mathrm{s}^{-1}\right)$ were observed in river waters collected from the Kurose River, Hiroshima prefecture, Japan [8]. Therefore, it is conceivable that the high $\bullet \mathrm{OH}$ formation rates in Osaka bay are probably due to the influx of river waters which introduced various industrial and domestic waste waters to the bay.

Table 2: Hydroxyl radical photoformation rates in Seto Inland Sea

\begin{tabular}{|c|c|c|c|c|c|}
\hline \multirow[t]{2}{*}{ Sampling location } & \multirow[t]{2}{*}{ Date } & \multirow[t]{2}{*}{$\mathrm{n}$} & \multicolumn{3}{|c|}{ Photoformation rate $\left(10^{-12} \mathrm{Ms}^{-1}\right)$} \\
\hline & & & $\underline{\min }$ & $\underline{\max }$ & average \\
\hline Hiroshima bay & Sept. 2007 & 20 & 9.6 & 49.8 & 32.3 \\
\hline Aki nada & Oct. 2008 & 10 & 12.3 & 35.6 & 21.5 \\
\hline Bingo nada & Oct. 2008 & 5 & 7.2 & 18.2 & 13.5 \\
\hline Bisan seto & Oct. 2008 & 5 & 13.2 & 42.1 & 25.4 \\
\hline Harima nada & Oct. 2008 & 5 & 22.4 & 62.3 & 39.6 \\
\hline Osaka bay & Oct. 2009 & 5 & 128 & 424 & 284.5 \\
\hline
\end{tabular}

To get better insight into the sources of $\bullet \mathrm{OH}$ in the Seto Inland Sea, the concentrations of well-known $\bullet \mathrm{OH}$ sources, such as $\mathrm{NO}_{3}^{-}, \mathrm{NO}_{2}^{-}$and $\mathrm{H}_{2} \mathrm{O}_{2}$ were determined and were presented in Table 3. 
Determination of Hydroxyl Radical in Seto Inland Sea and its Potential to Degrade Irgarol

Table 3: Concentrations of $\mathrm{OH}$ radical sources in Seto Inland Sea

\begin{tabular}{|c|c|c|c|c|c|c|c|c|}
\hline \multirow{2}{*}{$\begin{array}{l}\text { Sampling } \\
\text { location }\end{array}$} & \multicolumn{2}{|c|}{$\mathrm{NO}_{2}^{-}(\mu \mathrm{M})$} & \multicolumn{2}{|c|}{$\mathrm{NO}_{3}^{-}(\mu \mathrm{M})$} & \multicolumn{2}{|c|}{$\mathrm{H}_{2} \mathrm{O}_{2}(\mathrm{nM})$} & \multicolumn{2}{|c|}{ DOC (ppm) } \\
\hline & Range & Mean & Range & Mean & Range & Mean & Range & Mean \\
\hline Hiroshima bay & $0.03-1.48$ & 0.69 & $0.4-6.38$ & 3.78 & $\mathrm{Nd}$ & $\mathrm{Nd}$ & $1.31-1.65$ & 1.40 \\
\hline Aki nada & $0.06-1.01$ & 0.25 & $0.7-3.82$ & 2.10 & $65-315$ & 178 & $1.10-1.32$ & 1.18 \\
\hline Bingo nada & $0.04-0.35$ & 0.18 & $0.4-2.46$ & 1.12 & $112-298$ & 210 & $1.04-1.12$ & 1.09 \\
\hline Bisan seto & $0.06-1.12$ & 0.53 & $0.9-3.65$ & 1.35 & $82-324$ & 162 & $1.11-1.34$ & 1.21 \\
\hline Harima nada & $0.03-1.04$ & 0.45 & $0.8-4.98$ & 2.08 & $78-332$ & 167 & $1.20-1.45$ & 1.28 \\
\hline Osaka bay & $0.54-3.51$ & 2.13 & $1.3-8.82$ & 4.78 & $85-354$ & 234 & $1.12-1.54$ & 1.35 \\
\hline
\end{tabular}

Nd: not determined

The percent contributions $(\%)$ from these sources to the total $\mathrm{OH}$ radical photoformation rates were calculated by using (6):

$\%=J_{\mathrm{i}} \times[\mathrm{i}] \times 100 / R_{\mathrm{OH}}$

As shown in Table 4, the percent contributions of $\mathrm{NO}_{2}{ }^{-}$to the total $\cdot \mathrm{OH}$ photoformation rates were in the range $3.3-73.2 \%$. These data suggest that $\mathrm{NO}_{2}{ }^{-}$, though low in concentration in surface waters, may be an important photochemical source of $\bullet \mathrm{OH}$ in upwelling regions because of its elevated $\bullet \mathrm{OH}$ photoformation rate constant. However, the percent contributions of $\mathrm{NO}_{3}{ }^{-}$and $\mathrm{H}_{2} \mathrm{O}_{2}$ to the total $\bullet \mathrm{OH}$ photoformation rates were in the range $0.2-2.8 \%$ and $0.21-5.2 \%$, respectively. This indicates that the contributions of $\mathrm{NO}_{3}{ }^{-}$and $\mathrm{H}_{2} \mathrm{O}_{2}$ to the total $\bullet \mathrm{OH}$ photoformation rates observed in this study were neglibible. The percent contributions from unknown sources were also estimated and the results showed that $45 \%$ to $81 \%$ of the $\mathrm{OH}$ radicals were photochemically formed from unknown sources other than the photolysis of nitrite, nitrate and hydrogen peroxide. As observed by Takeda et al [8], $\bullet \mathrm{OH}$ radical formation from unknown sources correlated with fluorescent matter (an index of $\mathrm{CDOM}$ ), suggesting that $\bullet \mathrm{OH}$ radical formation from unknown sources can be explained by the photolysis of CDOM.

Table 4: Percent contribution of $\bullet \mathrm{OH}$ photoformation (\%) from the photolysis of $\mathrm{NO}_{2}{ }^{-}, \mathrm{NO}_{3}{ }^{-}$and $\mathrm{H}_{2} \mathrm{O}_{2}$ in Seto Inland Sea.

\begin{tabular}{|c|c|c|c|c|c|c|c|}
\hline \multirow{3}{*}{$\begin{array}{l}\text { Sampling } \\
\text { location }\end{array}$} & \multicolumn{7}{|c|}{$\%$ contribution } \\
\hline & \multicolumn{2}{|l|}{$\mathrm{NO}_{2}^{-}$} & \multicolumn{2}{|c|}{$\mathrm{NO}_{3}^{-}$} & \multicolumn{2}{|l|}{$\mathrm{H}_{2} \mathrm{O}_{2}$} & \multirow[t]{2}{*}{ Unknown } \\
\hline & range & mean & range & mean & $\underline{\text { range }}$ & mean & \\
\hline Hiroshima bay & $7.2-73.2$ & 52.3 & $0.9-2.8$ & 2.4 & $\mathrm{Nd}$ & $\mathrm{Nd}$ & 45.3 \\
\hline Aki nada & $11.7-68.8$ & 28.5 & $1.3-2.4$ & 2.2 & $1.6-2.8$ & 2.6 & 66.7 \\
\hline bingo nada & $13.6-47.1$ & 32.6 & $1.2-3.0$ & 1.8 & $4.8-5.2$ & 5 & 60.6 \\
\hline Bisan seto & $10.7-64.2$ & 51.1 & $1.5-1.9$ & 1.1 & $2.0-2.3$ & 2.1 & 45.7 \\
\hline Harima nada & $3.3-40.9$ & 27.1 & $0.8-1.8$ & 1.1 & $1.0-1.6$ & 1.3 & 70.5 \\
\hline Osaka bay & $10.3-20.2$ & 18.3 & $0.2-0.4$ & 0.38 & $0.21-0.28$ & 0.26 & 81.1 \\
\hline
\end{tabular}

Nd: not determined

\subsection{Steady-state concentrations, Scavenging rates and Lifetimes of $\mathrm{OH}$ radical}

The steady-state concentrations, overall scavenging rates and the lifetimes of $\cdot \mathrm{OH}$ radicals in Seto Inland sea are presented in Table 5. Overall scavenging rate constants of $\cdot \mathrm{OH}$ in Seto Inland Sea were in the range $1.3-4.1 \times 10^{6} \mathrm{~s}^{-1}$, which are in good agreement with those reported by Zhou and Mopper [31] for coastal waters $\left(2.1-2.5 \times 10^{6} \mathrm{~s}^{-1}\right)$, and by Mopper and Zhou [1] for the open oceans $\left(2.5 \times 10^{6} \mathrm{~s}^{-1}\right)$. Previous investigators have shown that the scavenging of $\bullet \mathrm{OH}^{-} \mathrm{Br}^{-}$will consume about $93 \%$ of the $\cdot \mathrm{OH}$ production in seawater. Thus, approximately $7 \%$ of $\cdot \mathrm{OH}$ produced reacts directly with other components of seawater, including DOM [1]. Meanwhile, based on the second order reaction rate constant of bromide ion with $\cdot \mathrm{OH}$ determined in this study (data not shown) and the reported average concentration of bromide ion in the seawater $(\sim 860 \mu \mathrm{M})$, almost $96 \%$ of $\bullet \mathrm{OH}$ produced in the seawater reacts with bromide ion. Even though the observed - $\mathrm{OH}$ formation rates in Osaka bay are one order of magnitude higher than those reported previously, the overall scavenging rate constants determined in this bay were in excellent agreement with those earlier reported [1]. 
The steady state concentrations of hydroxyl radicals which were calculated from the photo-formation rates and scavenging rate constants ranged from $2.6 \times 10^{-18} \mathrm{M}$ in Bingo nada to $189 \times 10^{-18} \mathrm{M}$ in Osaka bay. In the same manner, the reason for the elevated steady state concentrations of $\cdot \mathrm{OH}$ in Osaka bay could be attributed to the exceptionally high formation rates of $\bullet \mathrm{OH}$ in the region since the scavenging rate constants determined in each region were relatively constant throughout the entire sea, corroborating the assertion that bromide ion is the major scavenger of hydroxyl radicals in seawater.

As shown in Table 5, the lifetimes of $\mathrm{OH}$ radicals in Seto Inland Sea range from 0.29 to $0.55 \mu$ s. The extremely short lifetimes of $\bullet \mathrm{OH}$ in seawater are reasonable because $\mathrm{OH}$ radicals react with the dissolved components in seawater at diffusion controlled rates $\left(\sim 10^{9} \mathrm{M}^{-1} \mathrm{~s}^{-1}\right)$. The results obtained in this study corroborate the report of Zhou and Mopper et al [31] who showed that the lifetimes of $\mathrm{OH}$ in coastal waters are in the range $0.47-0.4$ $\mu \mathrm{s}$.

Table 5: Overall scavenging rate constants, steady-state concentrations and lifetimes of $\mathrm{OH}$ radicals in Seto Inland Sea

\begin{tabular}{|c|c|c|c|c|c|c|}
\hline \multirow[t]{2}{*}{$\begin{array}{l}\text { Sampling } \\
\text { location }\end{array}$} & \multicolumn{2}{|c|}{$\begin{array}{c}\text { Scavenging rate constant } \\
\qquad\left(10^{6} \mathrm{~s}^{-1}\right)\end{array}$} & \multicolumn{2}{|c|}{$\begin{array}{c}\text { Steady-state concentration } \\
\left(10^{-18} \mathrm{M}\right)\end{array}$} & \multicolumn{2}{|c|}{ Lifetime ( $\mu \mathrm{s})$} \\
\hline & $\underline{\text { range }}$ & $\underline{\text { mean }}$ & $\underline{\text { range }}$ & $\underline{\text { mean }}$ & $\underline{\text { range }}$ & mean \\
\hline Hiroshima & $2.6-4.1$ & 2.9 & $3.1-12.1$ & 11.1 & $0.24-0.38$ & 0.34 \\
\hline Aki nada & $2.2-2.9$ & 2.5 & $5.5-12.2$ & 8.6 & $0.34-0.45$ & 0.41 \\
\hline Bingo nada & $2.8-4.1$ & 3.4 & $2.6-4.4$ & 3.9 & $0.24-0.35$ & 0.29 \\
\hline Bisan seto & $2.5-3.2$ & 2.9 & $5.2-13.2$ & 8.7 & $0.31-0.42$ & 0.34 \\
\hline Harima nada & $2.7-3.6$ & 3.2 & $8.2-17.4$ & 12.5 & $0.27-0.37$ & 0.32 \\
\hline Osaka bay & $1.3-2.2$ & 1.8 & $101-189$ & 158 & $0.44-0.70$ & 0.55 \\
\hline
\end{tabular}

\subsection{Determination of second order rate constant of Irgarol with hydroxyl radicals}

We employed the standard competition kinetics method to determine the reaction rate constant of irgarol with $\bullet \mathrm{OH}$ in air-saturated aqueous solution. Hydroxyl radical was generated by irradiating $1 \mathrm{mM} \mathrm{NO}_{3}{ }^{-}$in a 20 -mL quartz cell. Benzene reacts with $\cdot \mathrm{OH}$ in air-saturated solution yielding phenol, with a second order reaction rate of $7.8 \times 10^{9} \mathrm{M}^{-1} \mathrm{~s}^{-1}$ [15]. In experimental solution containing benzene without any other $\cdot \mathrm{OH}$ scavenger, all $\bullet \mathrm{OH}$ formed reacts with benzene to produce phenol. The total amount of phenol formed under this condition is denoted as [phenol] $]_{\mathrm{o}}$. However, if irgarol is present in the experimental solution with benzene, both reactants compete for the $\cdot \mathrm{OH}$ produced which leads to the attenuation of the signal intensity of phenol compared to the reaction of benzene with $\cdot \mathrm{OH}$ in the absence of irgarol. In this system, the amount of phenol formed is a fraction of the total $\bullet \mathrm{OH}$ generated which is denoted as phenol '.

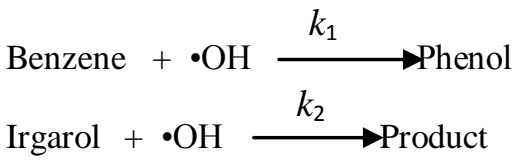

In this study, we carried out a series of experiments by 10 -min irradiation of $1 \mathrm{mM} \mathrm{NO}_{3}{ }^{-}$with $20 \mu \mathrm{M}$ irgarol varying the concentration of benzene from $(20-80 \mu \mathrm{M})$. However, to determine the concentration of the [Phenol] $]_{\mathrm{o}}$, a $1 \mathrm{mM} \mathrm{NO}_{3}{ }^{-}$was irradiated with $200 \mu \mathrm{M}$ benzene in the absence of irgarol for $10 \mathrm{~min}$. It has been established that $200 \mu \mathrm{M}$ benzene is sufficient to effectively scavenge all $\bullet \mathrm{OH}$ formed from $1 \mathrm{mM} \mathrm{NO}_{3}^{-}$[34]. Using equation 8, A plot of [phenol $]_{\mathrm{o}} /[$ phenol ]' vs [irgarol] / [ benzene] for separate experiments with solutions of varying [irgarol] / [ benzene] ratio is shown in Fig. 3, where [phenol] ' and [phenol] o are the concentrations of phenol produced fi $k_{1}$ he reaction of benzene and $\cdot \mathrm{OH}$ in air-saturated solutions with and without irgarol respectively, [irgarol ] is the initial concentration of irgarol, [benzene] is the initial concentration of benzene, $k_{2}$ is the reaction rate constant of irgarol with $\bullet \mathrm{OH}\left(\mathrm{M}^{-1} \mathrm{~s}^{-1}\right)$ and $k_{1}$ is the reaction rate constant of benzene with $\cdot \mathrm{OH}\left(\mathrm{M}^{-1} \mathrm{~s}^{-1}\right)$.

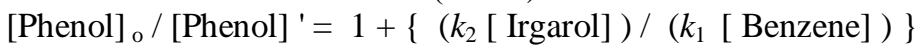


Thus, the value of $k_{2}$ estimated from the slope of this graph based on equation 9 was $(9.7 \pm 0.52) \times 10^{9} \mathrm{M}^{-1} \mathrm{~s}^{-1}$ (mean \pm standard deviation, $\mathrm{n}=3$ ).

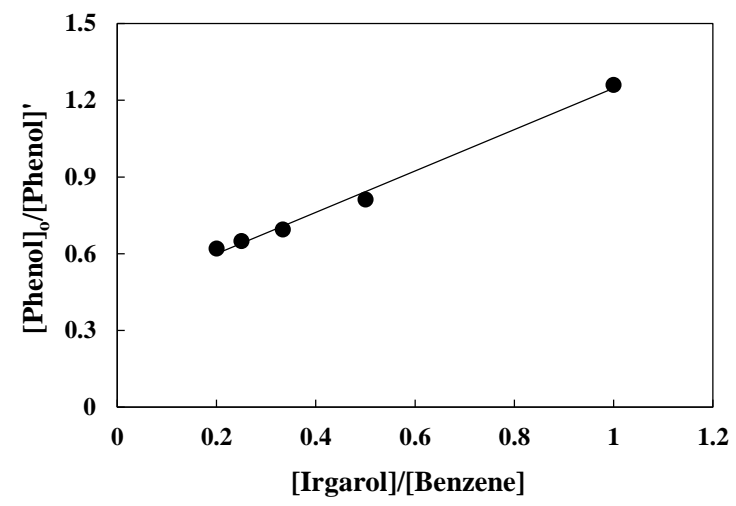

Figure 3: Graph for the reaction of the rate constant for the reaction of Irgarol with hydroxyl radical. The values for the y-intercept and slope are 0.4379 and 0.8093 , respectively. Correlation coefficient $\left(r^{2}\right)=0.9938$

\subsection{Environmental significance of $\mathrm{OH}$ radicals in seawater}

Hydroxyl radicals play an important role because of the elevated reaction rate constants towards a very wide variety of organic and inorganic compounds [15]. Due to its high reactivity with organic compounds, $\bullet \mathrm{OH}$ has been implicated in the degradation of recalcitrant organic compounds that are resistant to chemical, biological and direct photochemical decomposition. To examine the potency of $\mathrm{OH}$ radicals to degrade irgarol in seawater, we calculated the half-life $\left(\mathrm{t}_{1 / 2}\right)$ of the herbicidal compound, Irgarol, based on the $\bullet \mathrm{OH}$ steady-state concentrations determined in this study and the results of our preliminary studies on the rate constant for the reaction of $\bullet \mathrm{OH}$ with irgarol. Using the rate constant for the reaction of $\bullet \mathrm{OH}$ with irgarol, $k_{\mathrm{OH} \text {-irgarol }}$, of $(9.7 \pm$ $0.52) \times 10^{9}$ and the $\cdot \mathrm{OH}$ steady-state concentrations determined in this study $\left(2.6-189 \times 10^{-18} \mathrm{M}\right)$, the calculated half-lives for Irgarol in the Seto Inland Sea due to the reaction with hydroxyl radicals, based on equation (10), were in the range 4.3-318 days.

$$
\mathrm{t}_{1 / 2}=\ln 2 / k_{\mathrm{OH} \text {-irgarol }} \times[\cdot \mathrm{OH}]_{\mathrm{ss}}
$$

These data suggest that the reaction of $\bullet \mathrm{OH}$ with Irgarol may be an important pathway for Irgarol degradation in the Seto Inland Sea, especially in region with high $\bullet \mathrm{OH}$ production, such as the Osaka bay.

\section{CONCLUSION}

Photo-chemical formation of $\mathrm{OH}$ radicals in seawater samples has been investigated using benznene as a probe of $\mathrm{OH}$ radicals. Competition kinetics method was also employed to determine the rate constant for the reaction of hydroxyl radicals with irgarol. The steady state concentrations of $\bullet \mathrm{OH}$ in seawater, which were calculated from the photo-production rates and scavenging rate constants were in the range $2.6-189 \times 10^{-18} \mathrm{M}$. The rate constant for the reaction $\bullet \mathrm{OH}$ with irgarol was found to be $(9.7 \pm 0.52) \times 10^{9} \mathrm{M}^{-1} \mathrm{~s}^{-1 .}$ Using the steady state concentrations of $\bullet \mathrm{OH}$ determined in this study and the rate constant for the reaction of with hydroxyl radicals, the estimated half-lives for Irgarol due to the reaction with hydroxyl radicals in the Seto Inland Sea were in the range 4.3-318 days. However, it should be noted that the steady-state $\cdot \mathrm{OH}$ concentrations in surface waters are calculated only based on the light flux representative of noon solar radiation intensity on May 1 , 1998. Therefore, the steady-state concentrations of $\bullet \mathrm{OH}$ may tend towards the upper limit and the time-weighted average $\cdot \mathrm{OH}$ concentration may be less because of the variations in the solar irradiance by the time of the day. Hence, the estimated half-lives for Irgarol due to the reaction with hydroxyl radicals in the Seto Inland Sea might not be definitive because of the uncertainties inherent in the calculation of the steady concentrations of hydroxyl radicals.

\section{Acknowledgements}

The authors acknowledge with thanks the Japan Society for the Promotion of Science for financial support through a Grant-in-Aid for Scientific Research (B) (18310010).

\section{REFERENCES}

[1]. K. Mopper and X. Zhou, Hydroxyl radical photoproduction in the sea and its potential impact on marine processes. Science, 250, 1990, 661-664.

[2]. P. P. Vaughan and N. V. Blough, Photochemical formation of hydroxyl radical by constituents of natural waters. Environ. Sci.Technol. 32, 1998, 2947-2953.

[3]. W. J. Cooper, R. G. Zika, R. G. Petasne, and J. M. C. Plane, Photochemical formation of $\mathrm{H}_{2} \mathrm{O}_{2}$ in natural waters exposed to sunlight. Environ. Sci. Technol, 22, 1988, 1156-1160. 
[4]. H. Sakugawa, I. R. Kaplan, W. Tsai, and Y.Cohen, Atmospheric hydrogen peroxide. Environ. Sci. Technol. 24(10), 1990, 14521461

[5]. R. G. Zepp, B. C. Faust and J. Hoigne, Hydroxyl radical formation in aqueous reactions (pH 3-8) of iron(II) with hydrogen peroxide: The photo-Fenton reaction. Environ. Sci. Technol., 26, 1992, 313-319

[6]. B. M. Voelker, D. L. Sedlak and O. C. Zafiriou, Chemistry of Superoxide Radical in Seawater: Reactions with Organic $\mathrm{Cu}$ Complexes. Environ. Sci. Technol. 34, 2000,1036-1042.

[7]. T. Mill, D. G. Hendry and H. Richardson, Free- radical oxidants in natural waters, Science, 207, 1980, 886-887.

[8]. K. Takeda, H. Takedoi, S. Yamaji, K. Ohta, and H. Sakugawa, Determination of Hydroxyl Radical Photoproduction Rates in Natural Waters Anal. Sci., 20, 2004, 153-158.

[9]. O. C. Zafiriou, M. McFarland and R. H. Bromund, Nitric oxide in seawater. Science, 207, 1980, 637-639.

[10]. E. F. Olasehinde, K. Takeda and H. Sakugawa, Development of an analytical method for nitric oxide radical determination in natural waters. Anal. Chem., 81 (16), 2009, 6843-6850.

[11]. E. F. Olasehinde, K. Takeda and H. Sakugawa, Photochemical production and consumption mechanisms of nitric oxide in seawater. Environ. Sci. Technol., 44 (22), 2010, 8403-8408.

[12]. A. W. Vermilyea and B. M. Voelker, Photo-Fenton Reaction at Near Neutral pH. Environ. Sci. Technol. 43, 2009, $6927-6933$.

[13]. T. Arakaki, A. M. Hamdun, M. Uehara and K. Okada, Photochemical formation of hydroxyl radicals in red soil-polluted seawater on the North of Okinawa Island, Japan. Water, Air and Soil Pollut., 209, 2010, 191-198.

[14]. W. R. Haag, and J. Hoigne, Photosensitized oxidation in natural waters via OH radicals. Chemosphere, 14, 1985, 1659-1671.

[15]. G.V. Buxton, C. L. Greenstock, W. P. Helman and A. B. Ross, Critical review of rate constants for reactions of hydrated electrons, hydrogen atoms and hydroxyl radicals ('OH/ O-) in aqueous solutions. J. Phys. Chem. Ref. Data, 17, 1988, 519.

[16]. R. G. Zepp, J. Hoigné and H. Bader, Nitrate-induced photooxidation of trace organic chemicals in water. Environ. Sci. Technol., 21, $1987,443-450$.

[17]. G. Mark, H. G. Korth, H. P. Schuchmann and C. VonSonntag, The photochemistry of aqueous nitrate ion revisited. $J$. Photochem.Photobiol. A: Chem. 101, 1996, 89-103.

[18]. J. Mack, and J. R. Bolton, Photochemistry of nitrite and nitrate in aqueous solution: A review. J. Photochem. Photobiol. A: Chem. $128,1999,1-13$.

[19]. R. Zellner, M. Exner and H. Herrmann, Absolute $\mathrm{OH}$ quantum yields in the laser photolysis of nitrate, nitrite and dissolved $\mathrm{H}_{2} \mathrm{O}_{2}$ at 308 and $351 \mathrm{~nm}$ in the temperature range 278-353 K. J. atmos. Chem., 10, 1990, 411-425.

[20]. B. A. Southworth, and B. M. Voelker, Hydroxyl radical production via the photo-Fenton reaction in the presence of fulvic acid. Environ. Sci. Technol. 37, 2003, 1130-1136.

[21]. E. M. White, P. P. Vaughan and R. G. Zepp, Role of the photo- Fenton reaction in the production of hydroxyl radicals and photobleaching of colored dissolved organic matter in a coastal river of the southeastern United States. Aquat. Sci., 65, 2003, 402414.

[22]. T. Arakaki, T. Miyake, M. Shibata and H. Sakugawa, Photochemical Formation and Scavenging of Hydroxyl Radical in Rain and Dew Waters J. Chem. Soc. Jpn, 1998, 619-625.

[23]. T. Arakaki and B. C. Faust, Sources, sinks, and mechanisms of hydroxyl radical $(\bullet \mathrm{OH})$ photoproduction and consumption in authentic acidic continental cloud waters from Whiteface Mountain, New York: the role of the Fe(r) (r=II, III) photochemical cycle. J. Geophys. Res., 103, 1998, 3487-3504

[24]. H. Okamura, I. Aoyama, D. Liu, J. Maguire ' G. J. Pacepavicius and Y. L. Lau Photodegradation of Irgarol 1051 in water J. Environ. Sci. Health., B34, 1999, 225-238.

[25]. V. A. Sakkas, D. A. Lambropoulou and T. A., Albanis, Photochemical degradation study of Irgarol 1051 in natural waters: Influence of humic and fulvic substances on the reaction. J. photochem. Photobiol. A: Chem. 147 (2), 2002, 135-141.

[26]. B. Sarangaraja, K. Takeda and H. Sakugawa, Occurrence of Diuron and Irgarol in Seawater, Sediments and Planktons of Seto Inland sea, Japan. Geochemical Journal, 46, 2012, 169-177.

[27]. D. Liu, G. J. Pacepavicius, R. J. Maguire, Y. L. Lau, H. Okamura and I. Aoyama, Mercuric chloride-catalyzed hydrolysis of the new antifouling compound Irgarol 1051. Wat. Res, 33, 1999, 155-163.

[28]. W. L. Miller and D. R. Kester, Hydrogen peroxide measurement in sea water by (p-hydroxyphenyl)acetic Acid Dimerization . Anal. Chem, 60, 1988, 2711-2715.

[29]. K.Takeda and K.Fujiwara, Characteristics on the determination of dissolved organic nitrogen compounds in natural waters using titanium dioxide and platinized titanium dioxide mediated photocatalytic degradation. Wat. Res. 30, 1996, 323

[30]. E. F. Olasehinde, S. Makino, H. Kondo, K. Takeda and H. Sakugawa Application of Fenton reaction for nanomolar determination of hydrogen peroxide in seawater. Anal. Chim. Acta., 627 (2), 2008, 270-276.

[31]. X. Zhou and K. Mopper, Determination of photochemically produced hydroxyl radicals in seawater and freshwater. Mar. Chem., 30, 1990, 71-88.

[32]. H. Mitsuru and Y. Tetsuo, Analysis of change of red tide species in Yodo River estuary by the numerical ecosystem model Marine Pollution Bulletin, 57, 2008, 103-107.

[33]. H. Akira and S. Takayuki, Heavy metals and accumulation rates of sediments in Osaka Bay, the Seto Inland Sea, Japan. J. Oceanogr. Soc. of Japan, 41, 1986, 39-52.

[34]. N. Nakatani, N. Hashimoto and H. Sakugawa, An evaluation of hydroxyl radical formation in river water and the potential for photodegradation of bisphenol. Geochemical Society Special Publication, 9, 2004, 233-242. 